\section{Survey of Gooseberry Mite Infestation in Ribes $\mathbf{L}$.}

\author{
Kim E. Hummer ${ }^{1}$ and Joseph D. Postman \\ U.S. Department of Agriculture, Agricultural Research Service, National Clonal \\ Germplasm Repository, 33447 Peoria Road, Corvallis, OR 97333-2521
}

John Carter

Department of Horticultural Science, University of Minnesota, 1970 Folwell Avenue, St. Paul, MN 55108-6007

\section{Stuart C. Gordon}

Scottish Crop Research Institute, Invergowrie, Dundee, DD2 5DA, Scotland

Additional index words. Cecidophyopsis grossulariae, currants, gooseberries, genetic resources, germplasm, plant breeding, host plant resistance, temperate fruit, eryophyoid mites

\begin{abstract}
During Dec. 1997 and Jan. 1998, the gooseberry mite, Cecidophyopsis grossulariae Collinge, was observed to infest 48 currant and gooseberry (Ribes $L$.) cultivars in a field plantation in Corvallis, Ore. The mite was observed on 29 black currant, (Ribes nigrum $L$.), two red currant [Ribes rubrum $\mathrm{L}$. and $R$. sativum (Rchbch.) Syme], 12 gooseberry [R. uvacrispa L., R. oxyacanthoides var. setosum (Lindley) Sinnot], and three $R$. Xnidigrolaria Bauer cultivars and the hybrid $R$. nigrum $x$ R. pauciflorum Turcz. ex Pojark. A range of mite infestation levels was observed, with some cultivars not being infested, some with light infestation, having 1 to 100 adult mites per bud, and some heavily infested, with more than 100 mites per bud. On lightly infested buds, the mites were inside bud and leaf scales; in heavily infested buds, mites were also observed on floral primordia. Scales of infested buds were often loose and appeared more open than noninfested ones. Mite distribution varied by branch within a plant. Black currant cultivars with the heaviest infestation of $C$. grossulariae were of Scandinavian, Russian, Scottish, and Canadian origin. The Russian black currant cultivar Tunnaja was the most heavily infested with more than 1000 mites per bud. Floral primordia were damaged in heavily infested buds.
\end{abstract}

Reports of European eriophyoid mites on Ribes in North America have been few. Hewett (1915) reported the black currant gall mite, now called Cecidophyopsis ribis Westw., on cultivated black currants near Duncans, B.C., Canada. Batchelor (1952) reported C. ribis in enlarged terminal bud-galls of a native currant, probably $R$. sanguineum Pursh, on an old ballast dump site near the mouth of the Nisqually River in Washington. With the recent occurrence of the non-gall-forming gooseberry mite in the western United States (Amrine et al., 1994), and with the increasing interest in the development of a North American currant and gooseberry industry, prevention of the spread of the several species of eriophyoid mites in Ribes is imperative.

The gooseberry mite is common in England and Europe and has been confused on numerous occasions with the black currant

Received for publication 25 Aug. 1998. Accepted for publication 25 Nov. 1998. This research was sponsored by USDA-ARS CRIS 5350-21000-022-00D, the Minnesota Agricultural Experiment Station, Univ. of Minnesota Bush Sabbatical Supplement Program and the Scottish Office Agriculture, Environment and Fisheries Dept. (SOAEFD). We also thank Dr. Brian Fenton and P. Lava Kumar, SCRI, for undertaking the molecular analysis of the mites. The mites were studied at SCRI under the conditions of a license from SOAEFD. The cost of publishing this paper was defrayed in part by the payment of page charges. Under postal regulations, this paper therefore must be hereby marked advertisem ${ }^{\mathrm{e}} \mathrm{nt}$ solely to indicate this fact.

${ }^{1}$ To whom reprint requests should be addressed. gall mite (Amrine et al., 1994; Massee, 1928; Taylor, 1914). Before recognition as a separate species, the gooseberry mite was considered to be a non-gall-forming strain of $C$. ribis (Easterbrook, 1980). Morphologically these mite species differ in dorsal shield structure and placement of hairs (Amrine et al., 1994); however, for practical significance, the black currant gall mite vectors reversion disease, while the gooseberry mite has not been observed as a vector.

The gooseberry mite has been reported in New Zealand (Manson, 1984), and currently may be causing problems in Tasmanian gooseberries (A.T. Jones, pers. comm.). Recent taxonomic treatments identify the gooseberry mite as $C$. grossulariae Collinge (Amrine et al., 1994). Cecidophyopsis grossulariae has a much broader host range of Ribes species (Easterbrook, 1980) than does the black currant gall mite, lives on the underside of leaves during the spring and summer, and may cause leaf enations and some tissue necrosis (Easterbrook, 1980). In the fall, the mites migrate to the outer layers of green scales in axillary buds and spend the winter in the dormant buds (Easterbrook, 1980).

The gooseberry mite was first reported in North America in Apr. 1992, in Corvallis, Ore., Boonville, Calif., and at a number of nurseries in the Salem, Ore., vicinity (Amrine et al., 1994). At that time, the mite was observed on the underside of young gooseberry leaves. The initial Ribes field planting at the
Germplasm Repository, Corvallis, was burned in an attempt to eliminate the mite (Hummer, 1993), but it persisted despite this measure.

On 15 Dec. 1997, non-gall-forming eriophyoid mites were observed inside the outer bud scales of dormant buds of 'Brodtorp' black currant planted at the Repository in 1994. Preliminary observations of dissected dormant buds indicated that the infested plants occurred throughout many rows of the Ribes collection and that the degree of infestation varied with cultivar. Morphometric (Amrine et al., 1994) and molecular analyses (Fenton et al., 1993, 1995) confirmed the identity of the mite as Cecidophyopsis grossulariae Collinge. The objective of this study was to survey the extent of $C$. grossulariae infestation on black currants, red currants, and gooseberries in the Repository field collection.

\section{Material and Methods}

This survey was based on a natural infestation of gooseberry mite in field-grown Ribes. Between 15 Dec. 1997 and 26 Jan. 1998, 121 Ribes genotypes were examined for the presence of $C$. grossulariae. Samples of mites from infested Ribes species and cultivars were collected (Table 1) and examined with a sensitive molecular multiplex polymerase chain reaction (PCR) technique developed by Kumar et al. (1999). Single clones of each genotype were planted in a field collection in Corvallis, Ore. For each genotype, five branches evenly spaced from around the perimeter of the plant were collected, two buds from each stem were dissected under binocular microscopes $(\times 20$ to 80 ), and the bud scales, leaf and floral primordia examined for the presence of the mite. During the sampling period, adult mites, immatures, and eggs were observed within dormant black currant flower buds. The cool outside air temperature allowed adult mite survival but limited their activity. Adult mite infestation level was ranked as heavy (100 or more mites per bud); light (1-99 mites per bud); or none (no mites observed). In a second study, natural mite distribution within a field planting was observed for the black currant cultivars Polar, StorKlas, and Tunnaja; the red currant $R$. sativum cv. Fay; and the gooseberries, $R$. uva-crispa cvs. Poorman and Invicta, and $R$. oxyacanthoides var. setosum by examining four buds from each of three branches of each plant.

\section{Results and Discussion}

Mite identity was confirmed as C. grossulariae using multiplex PCR. Cecidophyopsis grossulariae infested dormant buds in 48 of the 121 Ribes genotypes observed (Tables 1, 2, and 3). Infested Ribes plants were observed throughout the field collection without a discernible distribution pattern; noninfested and heavily infested clones were often adjacent to one another. The plants were obtained from multiple sources; the black currants from foreign sources were released from U.S. National Plant Germplasm Quarantine in Beltsville, Md. The mites may have been introduced during propagation at the Repository, and have been present in some of the clones since field establishment in 1992. With such broad op- 
Table 1. Level of infestation of Ribes cultivars with gooseberry mite (Cecidophyopsis grossulariae Collinge) in a field plantation at Corvallis, Ore., during Jan. 1998. Heavy infestation $(H)=100$ or more mites per bud; light $(\mathrm{L})=1$ to 99 mites per bud.

\begin{tabular}{|c|c|c|}
\hline Cultivar or election & Origin & Mite infestation level \\
\hline \multicolumn{3}{|c|}{ Black currants (Ribes nigrum) } \\
\hline BRi 74020-6 & Sweden & $\mathrm{H}$ \\
\hline Baldwin & England & $\mathrm{L}$ \\
\hline Beloruskaja sladkaja & Belarus & $\mathrm{L}$ \\
\hline Ben Lomond & Scotland & $\mathrm{H}$ \\
\hline Ben Nevis & Scotland & $\mathrm{L}$ \\
\hline Ben Tirran & Scotland & $\mathrm{L}$ \\
\hline Blackdown & England & $\mathrm{L}$ \\
\hline Brodtorp $^{\mathrm{z}}$ & Finland & $\mathrm{H}$ \\
\hline Consort & Ontario, Canada & $\mathrm{L}$ \\
\hline Coronet & Ontario, Canada & $\mathrm{L}$ \\
\hline Cotswold Cross & England & $\mathrm{L}$ \\
\hline Crusader & Ontario, Canada & $\mathrm{L}$ \\
\hline Daniels September & England & $\mathrm{L}$ \\
\hline Doez Siberjoczk & Russian Federation & $\mathrm{L}$ \\
\hline Golubka seedling & Russian Federation & $\mathrm{L}$ \\
\hline Hystawneznaja & Russian Federation & $\mathrm{L}$ \\
\hline Invigo & Germany & $\mathrm{L}$ \\
\hline Kantata & Russian Federation & $\mathrm{H}$ \\
\hline Kerry & Ontario, Canada & $\mathrm{H}$ \\
\hline Jet $(\text { Malling Jet })^{\mathrm{z}}$ & England & $\mathrm{L}$ \\
\hline Polar $^{2}$ & Sweden & $\mathrm{H}$ \\
\hline Risager & Netherlands & $\mathrm{L}$ \\
\hline StorKlas ${ }^{z}$ & Sweden & $\mathrm{H}$ \\
\hline Strata & Germany & $\mathrm{L}$ \\
\hline Swedish Black ${ }^{2}$ & Sweden & $\mathrm{H}$ \\
\hline Tenah & Netherlands & $\mathrm{L}$ \\
\hline Tunnaja ${ }^{z}$ & Russian Federation & $\overline{\mathrm{H}}$ \\
\hline Wellington XXX & England & $\mathrm{L}$ \\
\hline Westwick Choice & England & $\mathrm{L}$ \\
\hline \multicolumn{3}{|c|}{$\underline{\text { Red currants }}$} \\
\hline Fay $(R \text {. sativum })^{\mathrm{z}}$ & New York & $\mathrm{H}$ \\
\hline Rosetta (R. rubrum) & Netherlands & $\mathrm{L}$ \\
\hline \multicolumn{3}{|c|}{ Gooseberries, $R$. uva-crispa $=R$. grossularia } \\
\hline Achilles & Old European & $\mathrm{L}$ \\
\hline Careless & England & $\mathrm{L}$ \\
\hline Colossal & Minnesota & $\mathrm{L}$ \\
\hline Fredonia & New York & $\mathrm{L}$ \\
\hline Glenndale & New Jersey & $\mathrm{L}$ \\
\hline Hinnonmaen keltainen & Finland & $\mathrm{L}$ \\
\hline Invicta (Malling Invicta) ${ }^{\mathrm{z}}$ & England & $\mathrm{L}$ \\
\hline Pixwell & North Dakota & $\mathrm{H}$ \\
\hline Poorman ${ }^{z}$ & Utah & $\mathrm{L}$ \\
\hline Rosco & Netherlands & $\mathrm{L}$ \\
\hline Ross & Saskatchewan, Canada & $\mathrm{L}$ \\
\hline Schultz & Alaska & $\mathrm{L}$ \\
\hline \multicolumn{3}{|c|}{ Gooseberry-Currant Hybrids $R$. ×nidigrolaria Bauer } \\
\hline Josta & Germany & $\mathrm{L}$ \\
\hline ORUS 2 & Oregon & $\mathrm{L}$ \\
\hline ORUS 9 & Oregon & $\mathrm{L}$ \\
\hline \multicolumn{3}{|c|}{ Miscellaneous species } \\
\hline$R$. nigrum $\times R$. pauciflorum & & \\
\hline RIB 885 & Russian Federation & $\mathrm{L}$ \\
\hline $\begin{array}{l}\text { R. oxyacanthoides var. setosum } \\
\text { (Lindley) Sinnott RIB } 48.001\end{array}$ & Idaho & $\mathrm{L}$ \\
\hline
\end{tabular}

Identity of the gooseberry mite confirmed by molecular analysis.

Table 2. Numbers of gooseberry mites (Cecidophyopsis grossulariae Collinge) observed on single buds and branches of Ribes cultivars from a field plantation at Corvallis, Ore., in Jan. 1998.

\begin{tabular}{|c|c|c|c|c|c|c|c|c|}
\hline \multirow[b]{3}{*}{ Shoot } & \multirow[b]{3}{*}{ Bud } & \multicolumn{7}{|c|}{ Species } \\
\hline & & \multicolumn{3}{|c|}{ R. nigrum } & \multirow{2}{*}{$\frac{R \text {. sativum }}{\text { Fay }}$} & \multicolumn{2}{|c|}{ R. uva-crispa } & \multirow{2}{*}{$\begin{array}{c}\text { R. oxyacanthoides } \\
\text { var. setosum }\end{array}$} \\
\hline & & Tunnaja & Polar & StorKlas & & Poorman & $\overline{\text { Invicta }}$ & \\
\hline \multirow[t]{4}{*}{$\overline{1}$} & 1 & 1000 & 300 & 600 & 32 & 0 & 0 & 0 \\
\hline & 2 & 100 & 100 & 500 & 0 & 0 & 0 & 0 \\
\hline & 3 & 40 & 50 & 300 & 0 & 0 & 0 & 0 \\
\hline & 4 & 200 & 100 & 500 & 42 & 12 & 0 & 0 \\
\hline \multirow[t]{4}{*}{2} & 1 & 100 & 80 & 50 & 0 & 0 & 0 & 1 \\
\hline & 2 & 250 & 20 & 50 & 0 & 0 & 0 & 0 \\
\hline & 3 & 250 & 20 & 10 & 0 & 0 & 0 & 0 \\
\hline & 4 & 300 & 0 & 80 & 0 & 0 & 0 & 0 \\
\hline \multirow[t]{4}{*}{3} & 1 & 100 & 70 & 0 & 0 & 10 & 3 & 17 \\
\hline & 2 & 0 & 30 & 50 & 0 & 70 & 5 & 35 \\
\hline & 3 & --- & 150 & 20 & 0 & 45 & 20 & 0 \\
\hline & 4 & --- & 0 & 200 & --- & 70 & 8 & 0 \\
\hline
\end{tabular}

portunity for infestation, some of the variability in clonal susceptibility may be explained by genotype response.

The mite was observed on cultivars of black currant, red currant (Ribes sativum and $R$. rubrum), gooseberries ( $R$. uva-crispa, $R$. oxyacanthoides var. setosum), and hybrids $(R$. $\times$ nidigrolaria and $R$. nigrum $\times R$. pauciflorum) (Table 1). Easterbrook (1980) also observed that the host range of the non-gall-forming mite included these species.

Although the mites did not cause galling, we observed that the outer bud scales of some infested dormant buds became loose and were more open than the noninfested dormant buds. On lightly infested buds, the mites were present on the inside surfaces of bud and leaf scales; on heavily infested buds they damaged floral primordia. This contrasts with the observations of Easterbrook (1980), who stated that the non-gall-forming mites "were never found in the inner regions of the buds," even though some of the cultivars he inoculated contained as many as 1800 mites per bud.

Heavily infested buds had the greatest damage. The most heavily infested cultivar we observed was the Russian black currant cultivar Tunnaja, which had more than 1000 mites per bud (Table 2). Easterbrook (1980), following artificial inoculation, reported 1850 mites per bud on $R$. ×nidigrolaria $\mathrm{cv}$. B655/56, and 1800 per bud on black currant 'Westwick Choice,' as the highest infestation levels he observed. 'Westwick Choice' was only lightly infested under our conditions.

Mite distribution varied with branch within a plant. In the black currant 'Tunnaja,' the red currant 'Fay,' and the gooseberry cultivars Invicta and Poorman, the buds of some branches were infested while others were noninfested (Table 2). Branches with one infested bud tended to have many infested buds, while other branches of the same plant were noninfested (Table 2). The mites can disperse by moving within a stem. Those we observed in the laboratory with the binocular microscope were active, moving their legs and moving around on the bud scales.

Easterbrook reported that "large numbers of mites and eggs were found during the mild winter of 1972-1973." In 1997, the weather in Corvallis was slightly wetter and warmer than normal and the winter minimum was $-6.7^{\circ} \mathrm{C}$ (Taylor and Hannan, 1997). Those conditions are quite suitable for eriophyoid mite survival and may help to explain the heavy infestation in the Corvallis Repository field collection.

Massee (1932) reported that mite-infested buds of red currant and gooseberry did not develop normally in the spring and eventually dried out. During 1996 and 1997 we observed "blind" buds of red and black currants that never developed (unpublished data).

Easterbrook (1980) stated that $\approx 64 \%$ of the Scandinavian cultivars he observed were susceptible to mite infestation. We observed the five Scandinavian black currant cultivars, 'Brodtorp', 'StorKlas', 'Polar', 'BRi 740206', and 'Swedish Black', to be heavily infested with mites with serious damage to floral primordia in the first three. Heavy gooseberry 
Table 3. Ribes genotypes with no observed infestation of gooseberry mite (Cecidophyopsis grossulariae) in a field plantation at Corvallis, Ore., during Jan. 1998.

\begin{tabular}{|c|c|}
\hline Cultivar or selection & Origin \\
\hline \multicolumn{2}{|c|}{ Black currants, Ribes nigrum unless otherwise noted } \\
\hline Alagan & United States \\
\hline Amos Black & England \\
\hline Ben More & Scotland \\
\hline Bogatyr & Sweden \\
\hline Boskoop Giant & Netherlands \\
\hline Champion & England \\
\hline Kirovchanka & Russian Federation \\
\hline Laxton's Grape & England \\
\hline Laxton's Nigger & England \\
\hline Magnus & Ontario, Canada \\
\hline Malvern Cross & England \\
\hline Merton Cottage & England \\
\hline Minaj Smyroiv & Russian Federation \\
\hline Mopsy & Ontario, Canada \\
\hline Neosypujastaja & Russian Federation \\
\hline Nikkala XI & Sweden \\
\hline Nysa & Unknown \\
\hline Ojebyn & Sweden \\
\hline Ontario & Ontario, Canada \\
\hline Onyx & Unknown \\
\hline Otelo & Slovakia \\
\hline Pinot Debourksanof & France \\
\hline Pobeda & Sweden \\
\hline Rain-in-the-face ( $R$. americanum) & South Dakota \\
\hline Raven & England \\
\hline Royal de Naples & France \\
\hline Saunders & Ontario, Canada \\
\hline Schwarze Traube & Germany \\
\hline Seabrook's Seedling & England \\
\hline Slitsa & Netherlands \\
\hline Topsy & Ontario, Canada \\
\hline Trinder's Long Bunch & England \\
\hline Tsema & Netherlands \\
\hline Viola & Slovakia \\
\hline Wassil & Sweden \\
\hline Westwick Triumph & England \\
\hline Willoughby & Saskatchewan, Canada \\
\hline \multicolumn{2}{|c|}{ 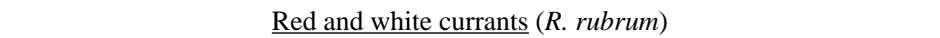 } \\
\hline Gloire des Sablons & France \\
\hline Rosa Hollandische & Netherlands \\
\hline Minnesota 52 & Minnesota \\
\hline Minnesota 69 & Minnesota \\
\hline New York 72 & New York \\
\hline $\mathrm{O}-271$ & Ontario, Canada \\
\hline Portal Ruby & England \\
\hline Redstart (Malling Redstart) & England \\
\hline Rolan & Netherlands \\
\hline Rovada & Netherlands \\
\hline Versailles & France \\
\hline White Currant 1301 & Sweden \\
\hline \multicolumn{2}{|c|}{ Gooseberries ( $R$. uva-crispa $=R$. grossularia $)$} \\
\hline Golda & Netherlands \\
\hline Gwens & England \\
\hline Jahns Prairie & Oregon \\
\hline Jumbo & Uncertain \\
\hline Lepaa punainen & Finland \\
\hline Sylvia & Ontario, Canada \\
\hline \multicolumn{2}{|c|}{ Gooseberry-Currant hybrids ( $R . \times$ nidigrolaria) } \\
\hline ORUS 7 & Oregon \\
\hline ORUS 10 & Oregon \\
\hline \multicolumn{2}{|c|}{ Miscellaneous Ribes species } \\
\hline R. americanum Miller (43) & Colorado \\
\hline$R$. bracetosum Douglas (902) & Washington \\
\hline R. ciliatum Humb. \& Bonpl. (670) & Popocatapetal, Mexico \\
\hline R. curvatum Small (102) & Texas \\
\hline R. coloradense Coville (296) & Colorado \\
\hline R. howellii Greene (449) & Idaho \\
\hline \multicolumn{2}{|l|}{ R. hudsonianum vetiolare } \\
\hline (Richards) Doug. (278) & Oregon \\
\hline R. janczewski Pojark (695) & Russian Federation \\
\hline R. komorovii Pojark (686) & Russian Federation \\
\hline R. lacustre (Pers.) Poir. (51) & Idaho \\
\hline R. pauciflorum Turcz. (286) & Uzbekistan \\
\hline \multicolumn{2}{|l|}{ R. petraeum v. carpathium } \\
\hline (C.A. Mey.) Jancz. (684) & Uzbekistan \\
\hline R. sanguineum Pursh (669) & Washington \\
\hline R. turbinatum Pojark (1055) & Kazakhstan \\
\hline R. valdevianum Phil (669) & Chile \\
\hline
\end{tabular}

z(Clone no.) mite infestation reduced the cold hardiness of dormant black currant buds (Carter and Hummer, 1999). We also observed heavy mite infestation in two Russian, one Scottish, and one Canadian cultivar (Table 1). By our observations, black currant 'Baldwin' and red currant 'Fay' had light gooseberry mite infestation, although Easterbrook (1980) suggested that these cultivars were resistant.

In summary, $\approx 40 \%$ of the Ribes genotypes examined were infested with gooseberry mites. The host range for this mite included major cultivars of black currants, red currants, and gooseberries. In heavily infested buds, mites occurred internally on leaf and floral primordia in addition to bud and leaf scales. Mite distribution varied by branch within a plant.

Cecidophyopsis grossulariae has not been recognized as an economic problem in commercial plantings in Europe (Easterbrook, 1980) but should not be overlooked as a potential pest in the development of the Ribes industry in North America. The heavily mite-infested dormant buds we observed in Corvallis, Ore., had flower bud damage and would have had significantly reduced yields.

During this study we observed an entomopathogenic fungus that was parasitic on $C$. grossularia. This fungus, once identified, extracted, and cultured may have potential as a biological control for this eriophyoid mite.

This survey of gooseberry mite presence in Ribes genotypes will be of use to plant breeders, who wish to introduce resistance to multiple mite strains or species and guard against a mite-population shift that could bypass the resistance.

\section{Literature Cited}

Amrine, J.W., G.H. Duncan, A.T. Jones, S.C. Gordon, I.M Roberts. 1994. Cecidophyopsis mites (Acari Eriophydae) on Ribes spp. (Grossulariaceae). I. J. Acarol. 20:139-168.

Batchelor, G.S. 1952. The eriophyoid mites of the state of Washington. Wash. State Univ. Tech. Bul. 6., Pullman.

Carter, J. and K.E. Hummer. 1999. Mite infestation decreases the cold hardiness of black currants. HortScience 34:218-220.

Easterbrook, M.A. 1980. The host range of a 'non-gallforming' eriophyid mite living in the buds on Ribes. J. Hort Sci. 55:1-6.

Fenton, B., G. Malloch, R.M. Brennan, A.T. Jones, S.C. Gordon, W.J. McGavin, and A.N.E. Birch. 1993. Taxonomic evaluation of three reputed species of Cecidophyopsis mites on Ribes. Acta Hort. 352:535-538.

Fenton, B., G. Malloch, A.T. Jones, J.W. Amrine Jr., S.C. Gordon, S. A'Hara, W.J. McGavin, and A.N.E. Birch. 1995. Species identification of Cecidophyopsis mites (Acari: Eriophyidae) from different Ribes species and countries using molecular genetics. Mol. Ecol. 4:383-387.

Hewett, C.G. 1915. Two series [sic] fruit pests new to Canada. Agr. Gaz. Can. 2:732-737.

Hummer, K. 1993. Proc. for the Ribes risk assessment workshop. USDA-ARS NCGR Sta. Pub. Corvallis, Ore.

Kumar, P.L., B. Fenton, and A.T. Jones. 1999. Identification of Cecidophyopsis mites (Acari: Eriophyidae) based on variable simple sequence repeats of ribosomal DNA internal transcribed spacer-1 sequences via multiplex PCR. Insect Mol. Biol. (In press.)

Manson, D.C. 1984. Eriophyoidea except Eriophyinae (Arachnida: Acari). Fauna of New Zealand No.4.Dept of Sci. and Ind. Res., Wellington.

Massee, A.M. 1928. The black currant gall mite on red currants. Rpt. East Malling Res. Sta. 1926-27. Suppl. II: $151-152$.

Taylor, A.M. 1914. Eriophyes ribis on Ribes grossularia. J. Agr. Sci., Cambridge 6:129-135.

Taylor, G. and C. Hannan. 1997. Weather summary for Corvallis, OR.Ore.Climate Serv., Ore. State Univ., Corvallis. 